\title{
バスとタクシーを融合した新しい公共交通 サービスの概念とシステムの実装
}

\author{
中島 秀之1・野田 五十樹2・松原 仁 3 ・平田 圭二 3 ・ \\ 田柳 恵美子 3 ・白石 陽 4 ・佐野 渉二 5 ・小柴 等6 ・金森 亮7 \\ 1非会員＼cjkstart公立はこだて未来大学学長（†041-8655 函館市亀田中野町116-2） \\ E-mail: h.nakashima@fun.ac.jp \\ 2非会員 産業技術総合研究所 サービス工学研究センター（†305-0821 茨城県つくば市梅園1-1-1） \\ E-mail: i.noda@aist.go.jp \\ 3非会員 公立はこだて未来大学教授 システム情報科学部（テ041-8655 函館市亀田中野町116-2） \\ E-mail: \{matsubar $\mid$ hirata $\mid$ tayanagi\}@fun.ac.jp \\ 4非会員＼cjkstart公立はこだて未来大学准教授 システム情報科学部（テ041-8655 函館市亀田中野町116-2） \\ E-mail: siraisi@fun.ac.jp \\ 5非会員＼cjkstart公立はこだて未来大学特別研究員（干041-8655 函館市亀田中野町116-2） \\ E-mail: sano@fun.ac.jp \\ 6非会員＼cjkstart文部科学省 科学技術・学術政策研究所（†100-0013 東京都千代田区霞が関3-2-2） \\ 7正会員 名古屋大学特任准教授 未来社会創造機構（干464-8603 名古屋市千種区不老町） \\ E-mail: kanamori.ryo@nagoya-u.jp
}

\begin{abstract}
バスとタクシーの区別を無くした，主として都市部を対象とした新しい公共交通システム（Smart Access Vehicle System）の概念を示す。これは, コンピューターにより全ての車輛の位置と経路を管理し, 固 定路線やダイヤを持たず，乗合いで，デマンドに即時対応するシステムである。これを交通サービスのク ラウド化と呼ぶ。タクシーの利便性とバスの経済性を併せ持つことが可能である上に, 渋滞, 事故, 天候 変化, 災害などに柔軟に対応できる. 筆者らは函館市内において小規模な実験を行い, 数日間の完全自動 配車に成功している。
\end{abstract}

Key Words : Smart Access Vehicle System, Demand responsive transportation, Public transportation

\section{1. 背景}

日本は世界で最初に超高齢社会に突入し，現在もその 先頭を走っている．今後先進国のみならず，いずれは途 上国も迎える高齢社会の問題解決モデル先進国として, 日本の取り組み動向は世界中から注目されている．少子 化，超高齢化，それに伴う急速な人口減少，そして伝統 的な地域コミュニティの衰退が，否応なく地方都市の 人々を過疎化と孤立化の危機へと向かわせている.

高度成長期以降の都市化一クルマ中心社会の到来，中 心市街地の空洞化と郊外の大型ロードサイド店への商圈 の移行などを背景に，電車・バス等の公共交通は利用者 が急減してきたが，近年は公共財源の緊縮化も相まって, 大幅な路線減・便数减も回避できない状況にある。ここ
に来て過疎ともいえないような市街地においても移動難 民，買い物難民が急増しており，新たな公共交通システ 厶一特定地域運行型（STS：Special Transport System）/デ マンド運行型（DRT : Demand Responsive Transport）一の 導入が活発化している1). 地方の中小都市では，定時運 行路線バスの全面廃止を断行し，一般ユーザの利便性を 切り捨てて高齢者向け等の特定ユーザのみを対象とする デマンド交通への切り換えを図る例も登場するなど，ユ ニバーサルサービスとしての一般公共交通の行方が危ぶ まれている2.

一方で情報通信技術の急速な普及と発展により，社会 インフラや都市サービスの領域において，これまで考え られなかったようなスマートな（賢い）問題解決が実現 可能になっている. いわゆるスマートシティとかビッグ 
データとかいわれる潮流である．高度な情報インフラは, いまや都市機能の状況や人間の諸活動を非常にきめ細か いメッシュと複雑多岐にわたるレイヤーで，かつリアル タイムで把握し制御することが可能になっている．超高 齢社会における社会インフラ，都市サービスについては 従来, 効率化や利便性を指標として計画・運用がなされ てきたが，今後は情報のスマートな活用により，効率化 と利便性，さらには多様性を加えた高度な運用が実現可 能になる334).

こうした情報通信技術の発展を背景に，公共交通に対 する考え方も変革が可能である. 従来のデマンド型公共 交通は, 中小規模エリアで, かつ過疎地域の高齢者など 特定地域の特定ユーザを対象としなければ成立しないと 考えられてきた. 多くのデマンド型公共交通は, 従来, オペレータによる人的配車計画に依存しているため, 一 定の量を超えた乗客への対応や, 配車途上でのリアルタ イム対応などに制約があったからである。しかし乗客か らの予約受付と運行計画が，すべて高い信頼度でのコン ピュータ自動制御で可能になれば，特定多数・不特定多 数の乗客を対象に, 複数の交通手段 (バス, タクシー, さらには自家用車なども含めて）の横断的な乗り合いサ 一ビスの提供も不可能ではない. 従来の公共交通への固 定観念を捨てて，まったく新しい概念のフルデマンド型 の交通サービスのアイデアを導入できると考えている5). そのような問題意識のもとで，筆者らは2011年度より 新しいデマンド型交通システム「SAVS (Smart Access Vehicle System)」のの開発と実証実験に取り組んでいる7,8). 2013年秋から北海道函館市においてコンピュータシステ ムによる完全自動配車システムを持つフルデマンド型の 乗合い交通実証実験に着手し，世界で初めて複数台リア ルタイム完全自動配車実験に成功した．運行ルートや乗 降場所をまったく限定せず，運行中の予約もリアルタイ ムで受け付けながらルート変更を柔軟に行う乗合い交通 で，乗客がスマートフォン等でデマンドを出してからほ ぼ5分待ちでの配車を実現した.

SAVSの詳細は3章以降で述べるが，現在，過疎地等で 運行されているデマンドバスの都市全域版と位置付ける ことができる. また，固定路線を持たないだけでなく， 運行中もリクエストに応じてルートが変更できる点が従 来のデマンドバスと異なる. このように大規模リアルタ イムシステムのため，人手による介入は不可能で，オペ レータ無しの完全自動運行システムとなっている. 現状 ではドライバを必要とするが, 将来自動運転が実用化さ れた折には完全に自動化することが望ましい. SAVSは, 概念的にも, サービスの実態の面でも, 交通/移動分野 へのクラウド化の導入と考えるのが相応しい．モビリテ イクラウド化は，情報技術・人工知能技術の分野からの 最先端のアプローチであり，これまでの交通/移動サー
ビスの制度や慣習を根本から変革することになる. SAVSはこのモビリティクラウド化を実現する，世界初 のシステムである.

交通弱者に対するモビリティを確保するとともに，地 方都市などで公共交通の不便さからしかたなく自家用車 を運転している層にも利便性の高いモビリティを提供す ることで, 都市生活全体のレベルを向上させる．また， コンピュータ制御の自由度の高さを活かして, 他の都市 内サービス（レストラン，娛楽，ショッピング，医療 等）との連携をとることも可能になる. モビリティはそ のような新しい都市生活の土台の一つとなる.

本論文では，第一にデマンド型公共交通の現状と課題 を整理し，第二に情報分野の先端的研究の立場から移動 サービスのクラウド化・仮想化という新しい概念を提起 したうえで，第三に筆者らが推進しているSAVSの概要 と実証実験の成果について詳述し, 最後に今後の展開, 特に公共交通単独のサービスに留まらない多様なサービ ス連携についての展望を述べる．これまでのサービス供 給側と享受側の情報の流れをダイナミックに統合する技 術の導入により，10年後を見据えた超高齢社会にふさわ しい “スマートな” 社会インフラ, 都市サービスを再構 築していくことが, 本研究の究極的な目標である.

\section{2. デマンド応答型交通システム}

地域（コミュニティ）への土着性が強い高齢者9の増 加により, 公共交通に求められる役割も変化してきてい る. つまり, 通勤・通学の移動効率性向上を目指寸定時 定路線での大量集約輸送サービス提供から，交通弱者へ の対応などの福祉的視点のサービス導入が求められてい る ${ }^{10)}$. この対応として, 主に公共交通空白地域を持つ自 治体ではデマンド型交通システムが導入されている.

いくつかの自治体でフルデマンド方式に近い, 固定路 線や固定ダイヤを全く持たない公共交通方式が実施され ているが，これらは過疎地など移動困難者を抱える特定 地域に限ったものである ${ }^{11}$. また，これらは人手による 配車計画が中心で，コンピュータによる集中制御はほと んど普及していない. 東京大学（以後, 東大）が柏市で コンピュータシステムによる運行管理者の補助を行って いる12)のがほぼ唯一の例外である. またこれらのデマン ドバスシステムは（東大のコンビニクルを含め）事前

(発車前) の予約を基本としている. つまり, デマンド バスのルートをあらかじめ決めた上で運行が開始される. また，発車時刻まで固定されているものも多い.

\section{(1) 分類と現状}

デマンド型交通システムは「あらかじめ利用者側の要 
求を受け，それに応じて運行する乗合の交通機関」と一 般的に定義され，また事業形態は「乗合タクシー」であ り，「一般タクシー」ではなく, 事前申請の地域以外で サービス提供を行うことも制度上できない.

鈴木 ${ }^{13)}$ による，デマンド型交通システムは以下の4 通りに分類される.

・迂回ルート型

固定ルートには定時運行し，あらかじめ設定された 迁回ルートにデマンドがあったときのみに迂回運行 する

・一部区間デマンド型

一定の地点まで定時定路線運行し，その先の需要が 拡散する地域はデマンドがある地区の夕延長運行す る

・設定ダイヤデマンド型

路線とダイヤは予め設定され，デマンドがあったダ イヤのみ運行する

・区域型（フルデマンド型）

一定のエリアの中でデマンドに応じてフレキシブル に任意の停留所間を運航する。一部の停留所を固定 する場合，およそのダイヤ (時間帯) を設定する場 合がある.

最近は停留所を設定せずに任意で予約を受ける区域型 (フルデマンド型) の導入が増えており，予約・配車シ ステムも電話予約+手作業による経路選定+無線指示の アナログ方式の他，ICTを活用したNTT方式や東大方式 (コンビニクル12)）の導入事例がある ${ }^{13) .}$

現在のデマンド交通システムの導入目的に目を向ける と, 特定地域運行型（STS）といわれる, 高齢者や障害 者等の特定ユーザ向け（あるいは特定ユーザが多い特定 地域向け）の運行に限定されているのが実態である．例 えばスウェーデンでは早くから国の施策により，全土に わたって高齢者・障害者等向けの乗り合いタクシーを小 規模エリアごとに運行してきているが，近年はストック ホルムやヨーテボリ等の大都市でこれを中規模エリアの デマンドバス運行へ発展させると同時に, 運行エリアを 増やしてサービス規模を大幅に拡大している. しかし利 用客の多い都市中心部では, 従来の定時運行路線バスや 路面電車が中心となり, 周辺地域からのデマンド交通の 利用者が都市中心部一出る，あるいは都市中心部で移動 するには，中心部との隣接拠点から定時運行路線バスや 電車に乗り継ぐ必要がある. 他国・他地域においてもお おむ状状況は同様である13)。

日本国内では高齢化・過疎化が進む中小規模の地方都 市において，定時路線運行バスの全面廃止とデマンド交 通への全面移行の事例も出てきている. 例えば，岡山県 総社市では周辺地域から市街中心地まで乗り入れられる フルデマンド型交通が導入されたものの，この場合も高
齢者の用途目的に焦点を当てたデマンド交通に特化し， その他のユーザのニーズは切り捨てられているのが実態 である.いずれの都市においても，特定地域運行型を主 軸として多様なサービスが発展してきているものの, そ れらは独立・分散して運行されており，横断的に繋いで いくサービスの開発は遅れているといえる.

一方で地域公共交通としての一般タクシーの活用も注 目されつつあり ${ }^{14)}$ 15), 市民, 来訪者など利用者の多様な 移動ニーズに対して, 地域特性に応じた交通システムの サービス提供が益々求められている.

筆者らは都市全域で，用途を限定しない一般的公共交 通交通の新しいサービス形態の導入を目指している.

\section{(2) 移動サービスのクラウド化}

本研究の目的の一つは, 移動サービスのクラウド化で ある. 図-1に, 現在開発中のSAVSがクラウド化の対象 とする交通サービスを示した. 定時運行からリアルタイ ムデマンド運行まで, 多人数乗合からタクシーのような 乗合なしの運行までを自在に制御することを可能にする システムである. 一般にクラウド化というと, データを サーバ上に保存し，そのデータや計算パワーを必要に応 じていつでもどこからでも利用可能とすることを意味す る. 各自が自分専用のマシンやデータストレージを持つ のではなく, ネットワーク上の複数のハードウェア資源 を単一の論理資源に見せかけて使う技術がこれである.

ここでいう，移動サービスをクラウド化するとは，物 理的に移動サービスを提供するタクシー，バス，さらに 自家用車等の車輛の管理・運用と, 需要に応じて提供さ れる仮想化された移動サービスを分離し, 複数の乗客の 需要に対して, 必要な時に必要なだけの移動サービスを 生み出すことである.つまり, 従来の公共交通では夕ク シ一やバスが事業会社ごとに管理・運用していたが，全 車輛の管理・運用を共通のインフラとして実現するので ある．全車輛の管理・運用を共通インフラとすることで,

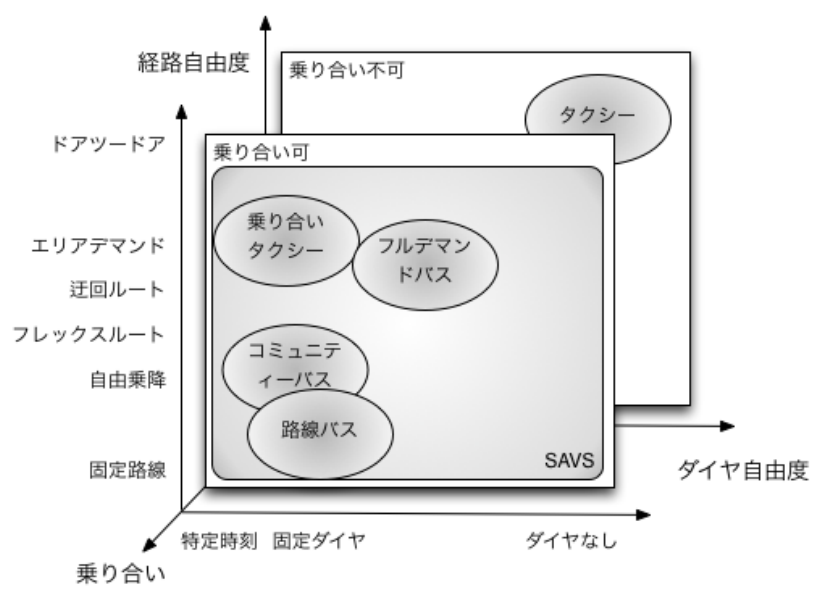

図-1 移動サービスのクラウド化の対象領域 
車輛や運行管理システムの運用や維持をより効率化でき る. 複数事業者の需要の増減を全体として吸収できるの で設備費の効率化も期待できる.

システム全体からみると，どの車輛がどんなサービス のために機能しているかは，システムの部分によってま た時間によって変化する，例えば，ある瞬間，何台かの 車輌はタクシーとして別の何台かはバスとして，さらに 別の何台かは乗合いタクシーとして機能する.1台の車 輌からみると，どの事業者のサービスを実現しているか が時々刻々と変わる，例えば，ある車轌は，事業者Aの バスとして機能した後, 事業者Bの乗合いタクシーとし て機能するかも知れない. さらに，異なる事業者の異な るサービスを受けている乗客や荷物が1台の車輛に乗り 合わせる場合もあろう。

移動サービスのクラウド化は運送・輸送事業者のビジ ネスモデルを変えるだろう。運送・輸送事業者は，その 時々で必要な量の移動サービスをクラウド化した移動サ 一ビスから購入し，付加価值を付けて顧客（乗客）に提 供するようになる，つまり，運送・輸送事業者はサービ ス業化し，その役割はそのインフラ上に高度なサービス を付加することに移る. 事業者は事業者ごとに異なるプ ライシングを行いサービスの創案を競ったり, サービス の連携や共創を試みたりすることが期待される.

移動サービスのクラウド化を実現するための技術的課 題は，事業者がサービスを設計・提供する際のプライシ ングに十分な情報と制御を提供することである. 具体的 には，ある状況で移動サービスの需要が生じた時，その 需要の実現に関する主要パラメータとして必要な燃料量, 移動時間, 移動距離が挙げられるので，ある需要が発生 した時にこの3点を予測する技術，いずれかのパラメー 夕を最適化する技術，妥当な選択肢を生成する技術の開 発が必要となる．配車アルゴリズム開発に関しては，最 小不幸や最大幸福など配車ポリシーの実現と切替え等の 技術課題が挙げられる.さらに社会実装のためには，多 様なユーザ層が使用できる快適なユーザインタフェース 誤操作や例外事象に対する頑健な動作，適応制御の実現 も重要である.これらについては対象地域の交通問題・ 課題の整理後の社会実験等を通じて，ユーザ一意向の把 握, 交通需要予測によるシナリオ分析を行っていく必要 がある。

将来的には様々な車輛を使い分け，その車輛にふさわ しい車内環境やサービスを分化させていくことになろう かとは思うが，我々はとりあえず現行のタクシーとバス という運行形態を統一することを手始めとしたい.

\section{3. スマートアクセスビークルシステム (SAVS)}

2013年10月にフルデマンド型公共交通として（筆者ら の知る限り）世界初の複数台リアルタイム完全自動配車 実験に成功した5).

本研究が提案するSmart Access Vehicle System（以下 SAVS，個々の車輛を指す場合はSAV，SAVの運行を意 味する場合はSAVサービスと呼ぶ）は以下の特徴を持 ว :

1. バスと同じ乗り合い方式であるが，タクシーと同 様に路線の規定をしない（原理的にはドアからド アへのサービスが可能であるが，効率の上からは 乗降場所をある程度限定した方が良い)

2. 事前予約を前提とせず，乗りたいときにSAVを呼 び出すことができる

3. 実時間で車両のルートを設定・管理する

4. 小数台を限られた地域で運行するのではなく, 都 市全体の公共交通機関（バスとタクシー）を集中 制御する. 即ち新しい公共交通機関の提案である

5. 過疎地域ではなく比較的人口の多い都市を対象と する

6. 都市間は別の大量輸送機関 (列車, 航空機, 船舶 等) で結ぶ

7. 料金体系に関してはまだ詳細を詰めていないが, タクシーよりは安く, バスよりは高い值段設定が 妥当と考えている

SAVサービスはユーザが乗りたいと思ったときに呼び 出す方式を採るが，タクシーと違い，乗車地点と降車地 点の両方を告げることにより，配車システムが最適の車 輛を選び出すようになっている. SAVSは固定経路を持 たず，呼び出しに応じて乗合いをしながら乗客を目的地 まで届ける.つまり, 従来のタクシーとバスを統合した ようなシステムになっている.

現在フルデマンド型の公共交通サービスは世界中で始 まっているが，SAVS以外はすべて特定地域を対象とし たものとなっている1)。これは実証実験等の結果から都 市部ではフルデマンド方式は効率が悪いとの結果を得て いるためであると推測される. 2000年4～6月に高知県で 行われた実証実験では，大人口の高知市では失敗し，小 人口の中村市で成功の後,「中村まちバス」として実用 化されている. しかしながら筆者らはシミュレーション において，これとは異なる結論を得た。 すなわち, 都市 部においては少数台の投入では（実証実験の結果通り） 効率が下がるが，ある程度以上の大量投入を行えば現状 より効率が改善される16,17), 18)ということが分かった．実 証実験では少数台の投入しか行われないため，効率の悪 い部分が出たと考えている，そのことを実証すべく，ま た函館市の公共交通問題を解決す心゙く，筆者らは函館全 
域でのSAVサービスの実現を目指している，函館市内の すべてのバスとタクシーを統合して運用するため, 従来 型のバスやタクシーは残らないという前提でデザインし ている.

ただし, SAVSは2.(2)で前述したとおり, 従来型の運 行をクラウド化対象として包含している．時刻表通りに バス停をつなぐという運行も, 電話での呼び出しに応じ たリアルタイム配車も, 駅や空港で多人数乗合の客待ち をすることも，1つのシステム上で運用可能である．実 際，朝夕の通勤時間帯など大勢の人が同じ方向に向かう ような場合は，SAVSの運行も自ずと定時路線バスとあ まり違わない運行形態となる. 必要とあればいつでもデ マンド運行をシステム上でOFFにして，従来のタクシー 型やバス型の運行に戻すことも可能である. その意味で 運行業者にとっては“リスクフリーで導入可能”である. 現状抱えている資産（運転手，車，時刻表，停留所，固 定需要等）や法制度上の制約に応じて, SAVS導入後も 従来型の運行を続けたり, 任意の時点でSAVSに参加し てSAVS型の運行に切替えるというようなことも可能で ある. 一見, 現在の交通システムと同じように運行させ ながら，漸進的にも抜本的にも実験や改変を進めていく ことが可能である. その意味で，これまでのような「新 しい交通方式の導入」とは次元の異なる，よりインフラ ベースの改革と捉えるべきものであり，ユーザへのモビ リティマネジメントも, クラウド化の導入対象や段階に 沿って計画していくことが望ましい.

いまや過疎地域や交通困難地域のみを対象とする特定 システムを導入するよりも，包括的なクラウド化を想定 したSAVSのようなシステムを導入する方が，投資回収 効果は高いといえる. 実際, 車載システムもタブレット 端末1台程度の投資で済むので安価である.

現在，デマンドバスを導入している自治体ではタクシ 一との競合が問題になっており, タクシー会社からのク レームが出ている例もある。総社市ではデマンドバス （一律300円）利用者に対して50円のタクシー補助券を 出し，別途タクシーの利用を推奨するなどの工夫をして いる. これらに対LSAVはバスとタクシーの両方を巻き 込んだシステムであり, 両運行業者にとっての乗客増加 を見込んでいる. 公共交通が便利になることにより自家 用車の必然性が減るとの期待である. タクシ一業者のす べてがSAVサービスに参加することを期待しており，タ クシーと競合するシステムではないことを強調しておき たい.

SAVSはコンピュータによる集中制御方式を採る。こ のため2.(2)で述べたような柔軟な運行が可能であり，従 来型の路線バスやタクシーの運行方式を完全に包含して いる. つまり，タクシーあるいはハイヤーのようにユー ザが独占する形態から, バスのように路線と停留所を固
定して使うこともできる.たとえば前者は観光，後者は 通勤・通学に適していると考えられる.

SAVに乗りたいユーザ (乗客) は以下の手順で呼び出 すことになる :

1. 現在位置と目的地を指定して配車をリクエスト （目的地を指定するところがタクシーの配車シス テムとの違いである)

2. サーバが最適車輛を選択 してユーザに通知. この 際にピックアップ予定時刻と目的地到着予定時刻 を提示する（複数のオプションを提示することも 可能であるから, 早い高額サービスと, 遅い低額 サービスからユーザに選択させることもできる）

3. ユーザが受け入れた時点でデマンドが成立する

4. 乗り合い方式であるため, 乗車後に別のデマンド が発生する場合がある。そのような場合でもあら かじめ示した到達予定時刻を超えるデマンドは受 け付けない

現在, タクシーの呼び出しアプリはいくつか提供され ているが，これは単に空車を呼び出すだけであるからシ ステム的には単純なものである.SAVSは乗合いを前提 としているので，現在乗客を乗せて運行中の車輛のルー 卜を変更することを含むため, システムとしては複雑に なる. 一方で, 空車のみの配車よりは稼働効率が高いた め, 車輛の時間あたりの乗車人数は増加する.

SAVSはバス等の大型車輛を含めた運行を想定してい るが，現在走行している公共交通車輛は5人乗り以下の 乗用車型タクシー，10人乗り程度のミニバン型タクシー, 中型バス，大型バスの4種類程度しかない. 特に 10 ３0 人乗り程度の車輛のバラエティの増加が望まれる. 特に 10 人乗り程度の車輛は乗客用ドアが1枚しかないうえに 車内通路が無いので乗合いには適さない. 複数ドア（各 座席列に1ドアが望ましい）の中型車輛の開発が待たれ る.

\section{SAVSの実装}

ユーザのリクエストに応じて最適の SAV が呼び出さ れるまでの手順は以下の通りである :

1. ユーザが現在位置と目的地を指定して配車をリク エスト

2. サーバが，筆者らの開発した逐次最適挿入法 ${ }^{19}$ を用 いて最適車輛を選択

3. 選択された車輛に新ルートを指示

4. 乗客に出向かえ時刻と目的地到着時刻を伝達

5. 乗客端末はSAVの現在位置, 車載端末は乗客の現 在位置を地四上に表示 


\section{(1) 全体構成}

SAVSは大まかには以下より構成される：

1. ユーザ[注1]がデマンドを入力するためのアプリケー ション (乗客App)

2. SAVドライバがデマンドを確認するためのアプリ ケーション (車載App)

3. デマンドに応じて最適な車輛と訪問順序を計画す る配車システム

4. また，これらのサブシステムはデータベースを介 したデータのやりとりによって連携を実現する (図-2)

これらのシステムにより, SAVS は人間のオペレータ を介寸ることなく，自動でデマンドの受付からアサイン までを行うことができる，全自動での対応は，SAV サ 一ビスの提供上重要であるのみならず，サービスを社会 実装寸る際に有用な特徵である.

全自動化を行うことで, 普段は一般のタクシー配車シ ステムとして使いながら，アルゴリズムを切り替えて特 定の日だけタクシーを SAV として運行する，というよ うな使用方法が可能となり，事業者らが実態を見ながら 徐々に SAVS を導入することが可能になる.

\section{（2）ユーザ端末と乗客App}

SAVS では，ユーザが配車リクエストを行うユーザ端 末の一つとしてスマートフォンを想定し．後述する実証 実験では，スマートフォン上に乗客 App をインストー ルして配車リクエストを行っている.

乗客 App（図-3）は，ユーザが自身のデマンドを入 力・通知・確認するためのアプリケーションである。 ユ 一ザは，SAV を利用したいときに乗客 App 上でデマン ドを入力して，配車リクエストを行う。デマンドとして は，乗車位置と降車位置（目的地）だけで可能であるが, オプションとして，乗車位置の目印や降車希望時刻を入 力することで，それぞれドライバとの待ち合わせを容易 にしたり，鉄道や航空機などの接続やユーザの予定に合 わせた配車リクエストを行える．デマンドを通知後，配 車システム (3.(3)) により SAV がアサインされると, いつごろ乗車・降車（目的地到着）できそうかという， 見込み時刻が表示される，ただし，配車システムにより 降車位置に降車希望時刻で到着できる SAV をアサイン できないと判断された時には, 配車リクエストは拒否さ れる．なお，これらのサービスを提供するために，乗客 App 起動中は適時ユーザの位置情報をサーバに送信して いる.

以下に，乗客Appの機能を記す。

1. SAVの配車リクエスト

乗車位置と降車位置を指定して，配車リクエスト を行う

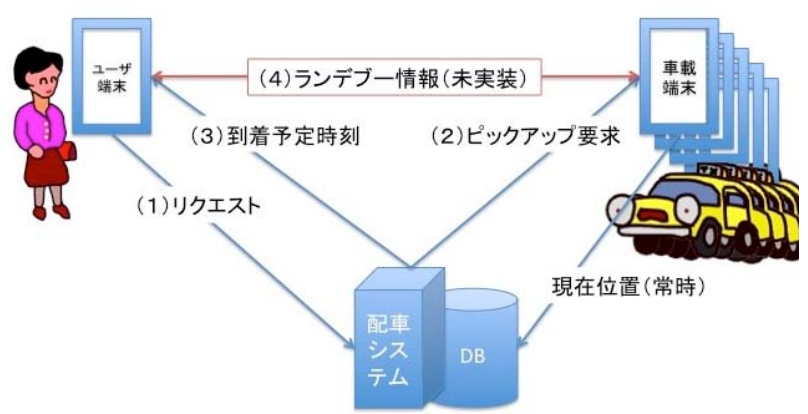

図-2ＳAV配車システム

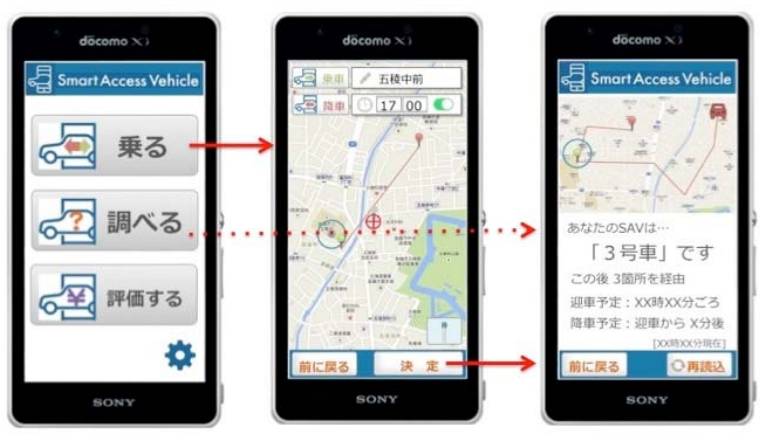

図-3 乗客Appの画面遷移

1.1. 乗車位置の指定

地図を操作して乗車位置を指定する．位置の指定 には，ランドマーク名からも行えるようにした。 ランドマークはアプリ起動時にサーバからダウン ロードされる，後述する実証実験では，函館市の 主な交通ターミナル，観光名所，レストランなど を用意した。また，乗車位置指定の際には，ドラ イバに通知する乗車位置の目印を文字で入力でき る

1.2. 降車位置の指定

乗車位置と同様に，地図を操作して降車位置を指 定する. ランドマークからも指定可能である. ま た，ユーザが予定に合わせた配車リクエストを行 えるように降車希望時刻の指定も行える

2. SAVの状況確認

乗客がSAVの状況やデマンドを確認する．配車リ クエスト前は，SAVの現在位置が地図上で表示さ れ, 配車リクエスト後は, 乗車位置, 降車位置や 到着予想時刻を表示される

3. アンケートの回答

実証実験時に乗客からSAVサービスに関するアン ケートを行えるようにした（結果は5.(5)に示す）

\section{(3) 車載端末と車載App}

ドライバに乗客の乗車位置・降車位置などを通知する ために, 各 SAVには車載 App がインストールされたタ 
ブレット端末を設置して使用する.

車載 App（図-4）は，ドライバに乗客の乗車位置・降 車位置とその訪問順序，それらの更新を随時通知寸るた めのアプリケーションである. 配車システム (3.(3)) で ユーザのデマンドが処理された結果, デマンドが SAV にアサインされると, その SAV に対応する車載 App に 音で通知すると共に，車載 App 画面上の乗客リストと 地図上の訪問順序を更新する。乗客リストには，乗せ間 違い防止のために乗客名, ユーザが乗客 App で入力し た乗車地点の目印情報が表示される.また，ドライバが 乗客の乗降をシステムに通知するためのボタン[注 2]を有 する，なお，配車システムがそれぞれの SAV の位置を 把握するために，車載 App は車輛の位置情報を定期的 にサーバに送信している.

以下に，車載 App の機能を記す.

1. 乗客の乗車位置・降車位置とその訪問順序の表示 配車システムでアサインされた乗客の乗車位置・ 降車位置とその訪問順序を表示する。また，乗客 リストとして乗客名, 乗客が入力した乗車地点の 目印を表示する．新たなデマンドがSAVにアサイ ンされるごとに，ドライバに知らせるために音で 通知するとともに，これらの情報を更新する

2. 乗客の乗車・降車の通知

乗客の乗車・降車についてサーバに通知をする. 乗客リストはボタンで作成しており，乗客が乗車， 降車する際に該当する乗客リスト中のボタンを押 して，サーバに通知する．乗客リストは訪問順に 表示するため, 多くの場合は乗客リスト中の先頭 に表示されているボタンに対して操作を行うが, 同じ場所で複数人が乗車・降車する場合を考慮し て，すべてのボタンに対して操作できるようにし ている

3. 他の機能

SAVの運行，休止についての通知を行う。配車シ ステムでは，運行中のSAVにだけ新たなデマンド をアサインするようになっており，休止中のSAV に対しては新たな乗客をアサインしない.また， 運行中にオペレータへ問い合わせるために，呼び 出し用のボタンを用意した

\section{(4) 配車システム}

配車システムはデマンドに対して適当な車輛 (SAV) を割り当てるシステムである.これが SAVS の要であり， 効率の良い乗合を実現する配車を実時間で行えなければ システムとして成立しない. 少数台の実証実験では車輛 選択の余地があまり無いが，SAVS は 1,000 台あるいは それ以上の規模の車輛数を想定している為, それらの中 から最良の（あるいはそれに準じた）一台を選ぶことが

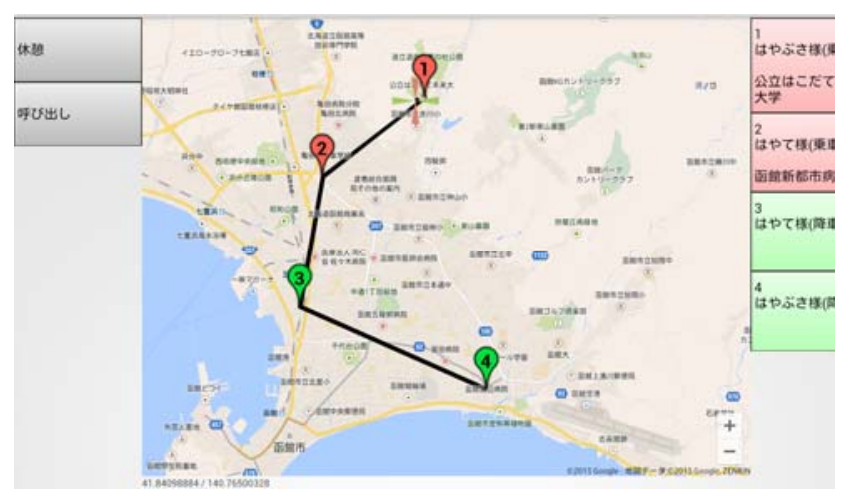

図-4 車載Appの画面

SAVSQUID

\begin{tabular}{|c|}
\hline $\begin{array}{c}\text { 網羅的シミュレーション基盤 } \\
\text { PRACTIS }\end{array}$ \\
\hline 配車コントローラ \\
\hline $\begin{array}{c}\text { 交通系シミュレータ } \\
\text { SUMO }\end{array}$ \\
\hline
\end{tabular}

図-5 SAVSQUIDの構成

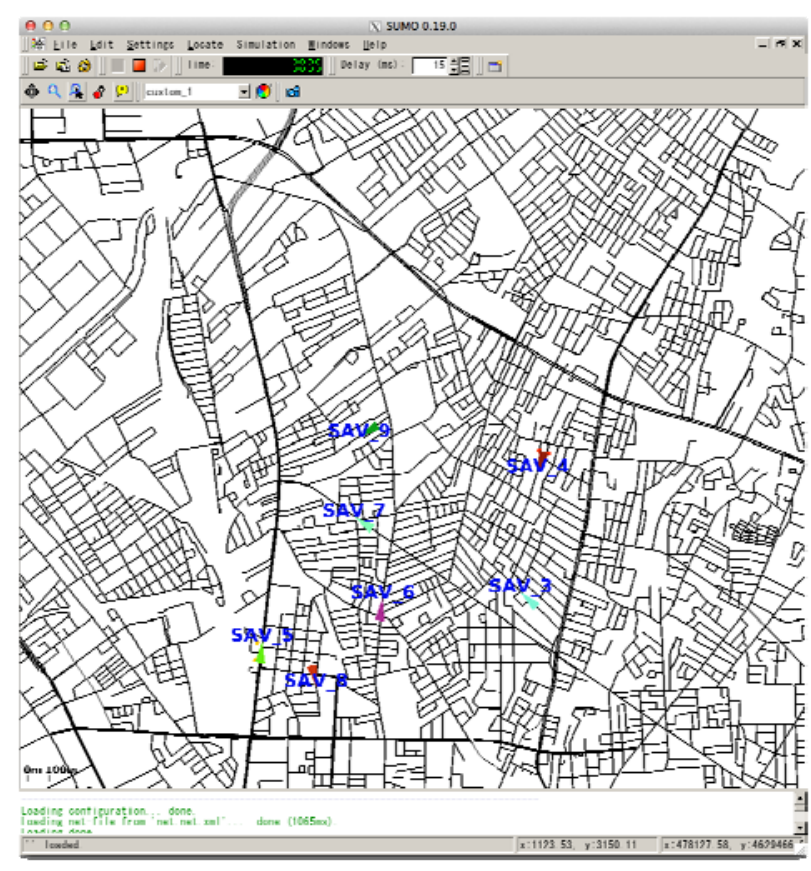

図-6 SAVSQUIDを用いたSUMOでの出力例

重要課題である. なお，以下に述べる現状のシステムは その意味ではまだ最適とは言えないがほぼ満足できるも のである.

現状の配車システムは SAVS のためのシミュレーショ ン基盤 SAVSQUID (SAVs Simulator for Qualitative Utility Investigation and Design）20（図-5）の機能限定版で，各車 輛の乗客数上限を盛り込んでいること以外に大きな差は ない.

移動所用時間の計算などのベースとしては交通シミュ レータ SUMO ${ }^{21)}$ 上に取り込んだ函館の道路地困（株式会 


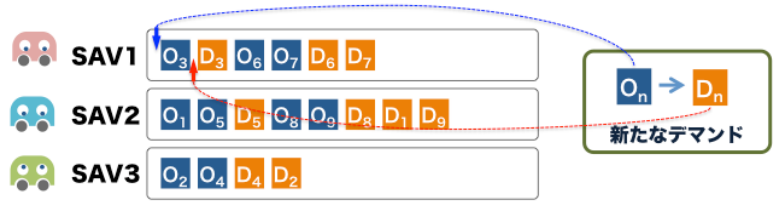

図-7 逐次最適扦入法

社ゼンリンの汎用デジタル道路地図データに基づく．許 諾番号: Z13LC 第 097 号, Copyright. 2013 ZENRIN CO., LTD.）を用いた（図-6）。

まず，対象エリア内における 2 地点間の最適経路と移 動時間を，他の車輛などが存在しない理想状態下で SUMO の提供する領欲法ベースの経路探索ツールを用 いて事前に算出し，結果を DB に記録しておく．その上 で，逐次最適挿入法 19）（図-7）により適切な SAV の探 索を行う。逐次最適挿入法は基本的に各車輛間での単純 オークションで淮最適解を求めるもので，車輛間での乗 客の交換は行わず，いったん車輛にアサインされたオー ダーの前後関係は常に保持される. また，乗客の指定し た締め切り時間をオーバーしたり, 徒歩で移動した方が 早くなると判断される場合には SAV へのデマンドのア サインを行わない，具体的な手順は以下である：

1. 新たにデマンドを配車システムが受けたときには, そのデマンドを各車輛に提示する

2. 各車輛は新規デマンドの出発（乗車）地点および 目的（降車）地点を各々, 現在の経由地点リス卜 の任意の箇所（全ての組み合わせ[注了）に挿入し， 挿入により生じる遅延を求める. これを元に新規 デマンドの達成予定時間（乗客を降万す時刻）を 求め, この達成予定時間と遅延の総和を挿入後の コストとする

3. 各車輛は2.のコストの最小值をもって入札する. た だし新しい挿入により, 既存あるいは新しいデマ ンドの締切り時間を過ぎてしまう場合は入札を行 わない

4. サーバは各車輛からのすべての入札のうちコスト 最小のものを選択し，その車輛にデマンドを配分 する

配車の計算はデマンドの発生に応じて都度行うことを 想定しており，現状ではデマンド情報が記録される DB を 15 秒ごとにチェックする[注 4]ことで行う．DB 上に新 たなデマンドが検出されると, 配車システムはその都度 計算を実行し，結果を DBに記録寸る。これにより乗客 App には乗降予定時刻/拒否を, 選択された車輛の車載 Appにはデマンドを通知する.

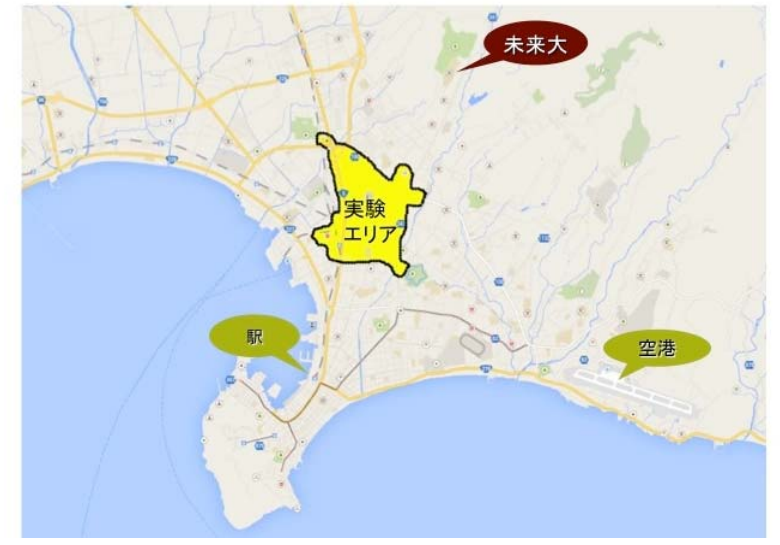

図-8 第1回実証実験エリア

\section{5. 実証実験}

実証実験は 2014 年 4 月までに 2 回実施した. 実験の 目標は主に以下のシステムを用いて実際に SAV の運行 （予約受付，配車計画，通信，実走）ができることの確 認である：

1. SAVユーザのための配車依頼システム（乗客App）

2. ユーザからのデマンドに応じて適切な車輛と訪問 順序を選定する配車システム

3. SAVのドライバのための配車指示システム（車載 App)

なお現状では SAV 運行の効率性（乗客をいかに目的 地に早く運べるか等）やユーザーの料金感度は実験の対 象としていない.

\section{(1) 第1回実験}

期間 : 2013年 10 月 24 日（木） 30日（水）7日間 場所 : 北海道函館市中心部の限定エリア (図-8)

車輛台数: 5 台（普通タクシー 3 台, 9 人乗りジャンボタ

$$
\text { クシー2台) }
$$

ユーザ : 事前募集の実験協力者 40 名程度

第 1 回の実験エリアは函館市街地である五稜郭からみ て北西に位置する約 $5 \mathrm{~km}^{2}$ のエリアで, 主要道路（基本 的にエリアの枠線内側に接する道路）沿いに病院や複数 のショッピングモール, 大規模電器店が点在し, 住宅街 なども含んでいる.一方で路線バスの乗り入れはほとん ど無いため自家用車利用が中心の地域である.

タブレット端末などの操作に慣れたドライバはほとん どいなかった，誰でも操作できるよう，ユーザインター フェース (UI) の改善が必要である.

乗客候補となる実験協力者を募集した結果, 38 名の 実験協力者を確保できた. 今回の実験では, 自宅や職場 からの利用も想定されていた. それらが乗降位置として 指定された場合に備え，プライバシー・個人情報保護の 観点から, 未来大の学生も含め, 基本的に実験協力者の 
募集と管理は NPO 法人に一任しており，個人情報は実 験者には開示されていない.

\section{(2) オペレーション支援システム}

実験モニタリングと故障時のマニュアル介入の為に, 各車の位置や，デマンドのアサイン状態を可視化（図9）するオペレータ向けのツールも用意した. 後述のよ うに，このシステムは実験前半で故障診断マニュアル介 入などに活躍したが，自動運転が可能となった後半では 単なるモニターとして使われた.

\section{(3) 第2回実験}

期間：2014年 4 月 27 日（日）

場所 : 北海道函館市中心部全域（図-10）

車輛台数 : 16 台（普通タクシー12 台，ジャンボタクシ -3台，小型バス 1台）（図-11）

ユーザ : サービス学会参加者のうち実験に協力してくれ た人 (50名程度)

第 1 回実験でシステムの稼働が実証されたため, 第 2 回実験では，第 1 回実験で Android のみであった端末を iPhone にまで広げるとともに，乗客用，車載用それぞれ のUIの改善とデバッグを行った.

ユーザとしては地域の実験協力者ではなく，函館市で 開催されたサービス学会全国大会に全国から訪れた参加 者に利用を呼びかけ，乗客 App をダウンロードして使 ってもらう方式を採った。 なお iPhoneアプリ配布の制限 や，道路交通法の問題を避けるため実験協力者にはあら かじめ NPO スマートシティはこだての賛助会員登録を してもらうこととした．今回の実験では旅行中のユーザ が主で職場や自宅が含まれないため，個人情報秘匿の配 慮は行わなかった。

SAV 運行エリアとしては, 学会参加者に函館観光を 楽しんでもらうべく第 1 回実験より大幅に広げ，空港か ら JR 函館駅前, 函館山や五稜郭公園など主要観光施設 を含んだものとした（図-10）。今回は 16 台を用意した が，特定サービスエリアでの最適な車輛台数については， 事前にシミュレーション評価すべきであり，今後 SAVSQUID で車輛台数やデマンド発生率を変化させた 分析により検証を行う予定である.

車載 App の UI も改善した（図-4 はこの改善版のUI）。 乗車（赤）上降車（緑）を色分けし，地図上の地点表示 との対応付けが容易になるようにした。 また左端に「休 蒩」「呼び出し」のボタンを配置した. ドライバからの 「休憩」リクエストが入ると配車システムはその SAV に新たなデマンドを割り付けない．乗車中の乗客がす心゙ て降車した時点でドライバは休憩に入れる. 休憩モード に入るとこのボタンは次の「運行開始」連絡ボタンに変 わる.「呼び出し」は乗客が見つからないなどのトラブ

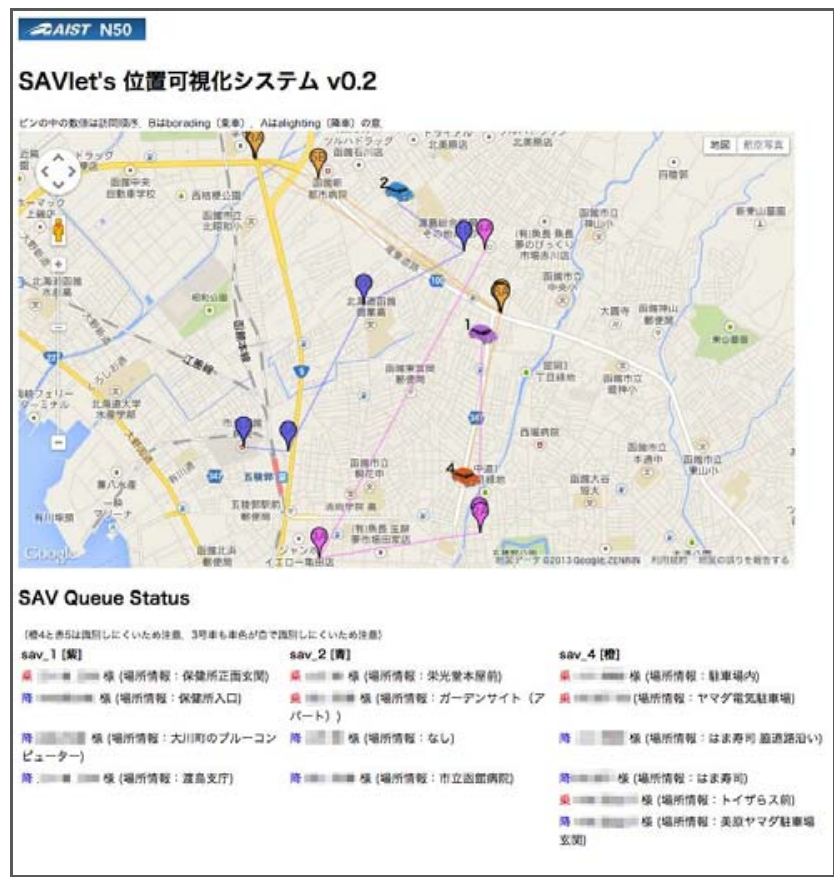

図-9 オペレーション支援システムの画面

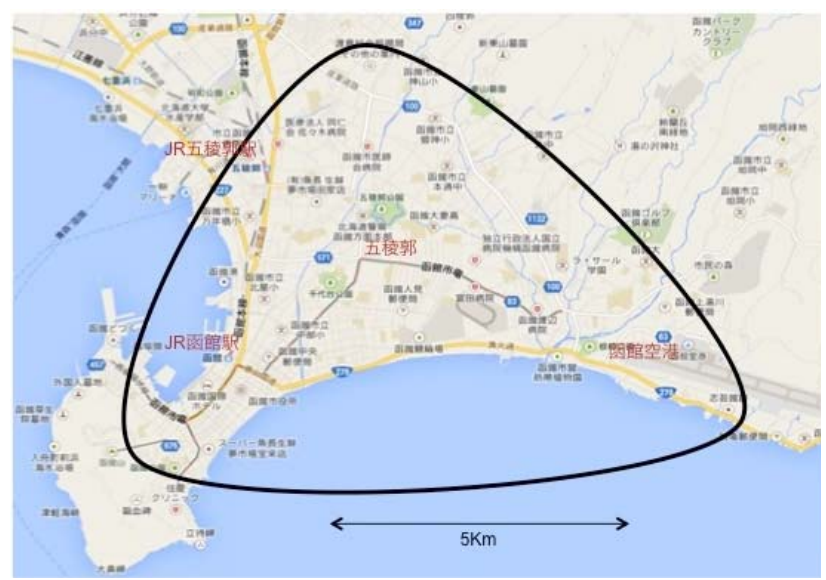

図-10 第2回実証実験エリア

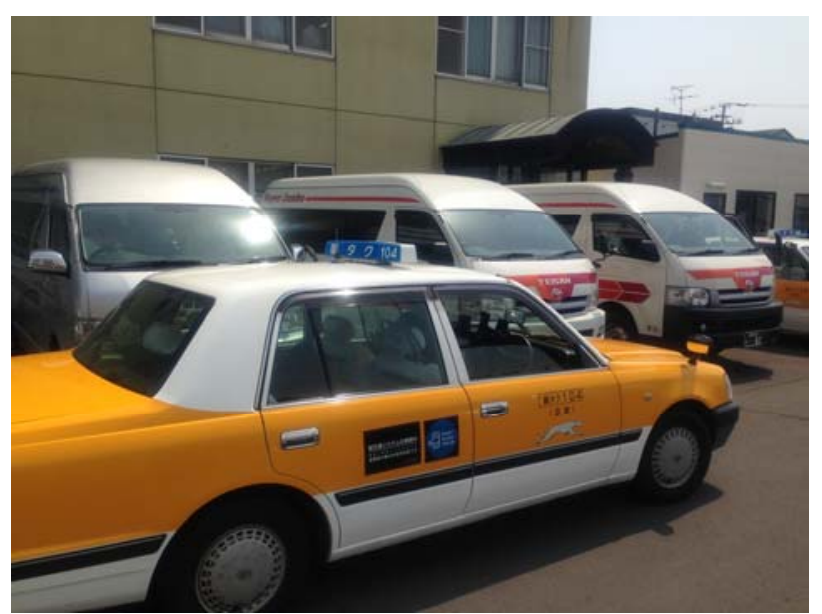

図-11 実証実験に用いた車輛（後部ドアに実験中 ステッカーを貼り，一般タクシーとの差別 化を図った. 奥はジャンボタクシー) 


\section{(4) 運行結果}

はじめにコンピュータによる SAVS の自動制御ができ るかのシステム稼働検証が主目的であった第 1 回実験の 期間の日別運行状況を図-12 に整理した. 実験初期（24 〜26 日）には様々なシステムトラブルが発生し，その 都度デバッグなどを行ったため運行データとしては意味 がないが，徐々に運行回数が増えていることが分かる. 最後の 4 日間（27〜30日）はトラブルなく運行できた期 間となる.この期間は通常の処理についてはオペレータ を介さずに自動的に行うことができた.

一般タクシーの函館市内での稼働レベルが 1 日あたり 25 件程度のデマンド処理であるため， 5 台で 125 件が運 行状況の基準となる. 今回の実験では 1 日約 170 件以上 のデマンドを受け付けたことから，一般タクシー以上の 数のデマンドに対し，ほぼ自動的に処理することができ たといえる. また，ほとんどの場合に 5 分以内の配車 (乗客のピックアップ) ができた. サービス範囲を広げ ても，第 1 回実験並み（1 $\mathrm{km}^{2}$ あた 1 台）かそれ以上の 車輛密度が確保できれば同等のサービスが維持できると 考えている. 函館市の中心部は約 $110 \mathrm{~km}^{2}$ なので, 現在 の全公共交通車輛 900 台を SAV として運行できれば, 単純計算で $1 \mathrm{~km}^{2}$ あたり約 8 台という計算になる。 デマ ンドの偏りを考慮しても十分と捉えているが，今後，デ マンドの時間的分布と空間的分布を算出し, 配車台数の 妥当性をシミュレーションにて検証していく予定である.

なお一般タクシーのデマンド処理数 125 件は 12 時間 以上の稼働で達成されているため, SAV が 11 時間の運 行時間であったことを考慮すると，170 件のデマンドは 十分な量といえる．ただし，SAVS が函館市街地におい て効率良くさばける 1 台当たりの最大デマンド数がどの 程度になるかについては今後の検証を待たねばならない。 以上により，

1. ユーザの要望（デマンド）に応じて,

2. 実時間内に適切・妥当な車輛と訪問順序を決定し,

3. SAVに通達し,

4. SAVが実際にユーザのデマンドを満たす,

という一連の動作を実現する SAVS が実際に構築・運用 できること，特に $2 ， 3$ の部分について人手を介さずに

（自動的に）達成できることが検証できた（これは第 2 回実験についても同様である）．複数のフルデマンド型 乗合い車輛のリアルタイム自動配車は筆者らの知る限り 世界初であり，1日あたり 11 時間の稼働を 4 日にわたり 維持できたことは，SAV サービスの社会実装を行う上 で有用な成果となった.

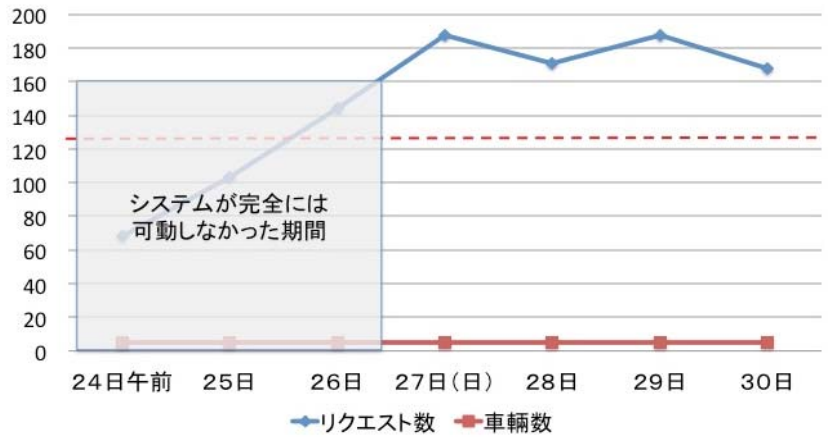

図-12 第1回実験（2013年10月）の運行状況

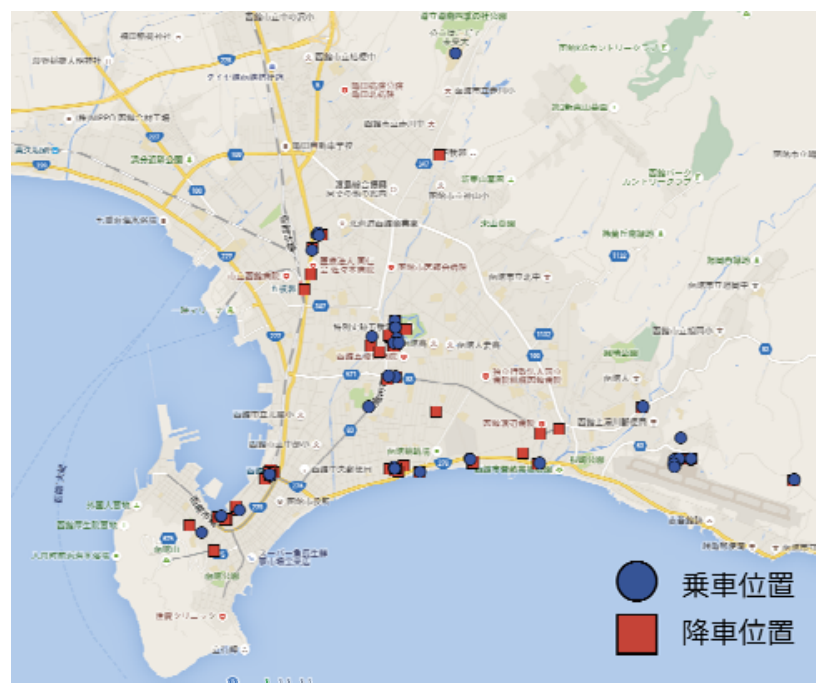

図-13 第2回実験（2014年4月）の乗降車場所

\section{(5) SAVの利用状況}

第 2 回実験結果では，市民ではなく学会参加者という 観光客に近い立場であるが，SAV 利用状況について考 察する. 第 1 回実験で成功したリアルタイム自動配車シ ステムにて，第 2 回実験では 11 18 時の 7 時間で 79 件 のデマンドを受付け，10 件のキャンセル（残念ながら 理由は把握できていない）を除き，58 件の配車がなさ れた（つまり，配車計算にて 11 件で利用者の乗合いが 発生）. 当初の想定よりもデマンド件数は少なく, サー ビス対象エリアは大きくなったが，システム稼働上の問 題はなかった.

実際に配車がなされたデマンドに着目し，デマンドの 空間的分布，配車時間と目的地到着時間の計算結果と実 際のサービス時の差をみる.

デマンドの空間的分布は図-13 の通り，空港や JR 函館 駅, 函館山付近や五稜郭公園を中心にした移動に利用さ れていることが分かる. 58 件の発着地点間の平均直線 距離は約 $4.2 \mathrm{~km} /$ 件, また平均乗車時間は 14 分/件であり, 一般タクシーであれば 1,500 円/回程度の移動となってい る.

次に利用者の配車までの待ち時間と目的地への到着時 


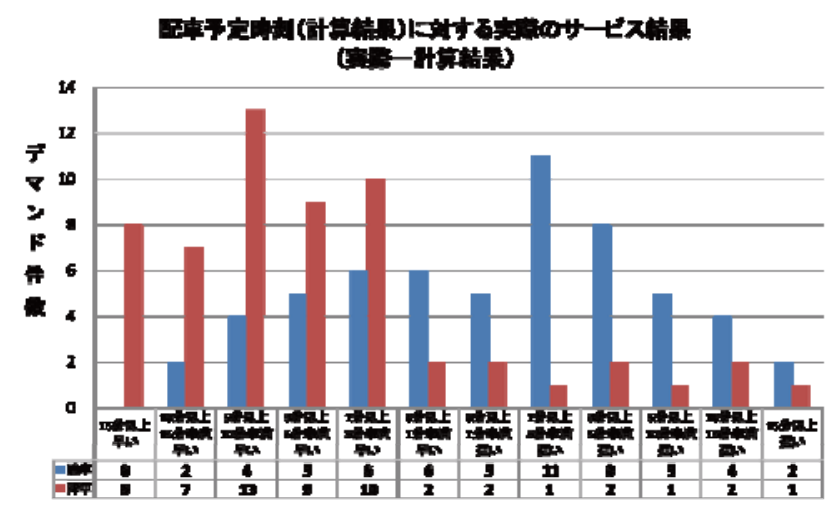

図-14 配車予定時刻と実際のサービス提供との差

間の計算誤差について確認する．図-14 はリクエスト受 付後に計算された配車予定時刻と実際の乗車時刻との差 （青色），目的地到着予定時刻と実際の降車時刻との差 （赤色）を整理したものである，なお，実際の乗車・降 車時刻は，運転手が乗車・降車ボタンを押した時刻であ る. 図より配車予定時刻に比べて目的地到着予定時刻は 計算結果よりも実際は早く到着していることが多いこと が分かる. 58 件の配車実績から，平均で配車予定時刻 は約 90 秒/件の遅延, 目的地到着予定時刻は 6 分/件の早 着となった. 目的地等到着予定時刻が早くなった理由と しては 4.(4)で説明した配車時に参照する地点間の最適 経路と移動時間の精度であり, 今後, SAV の走行実績 をプローブカーデータとして蓄積するなど，実際の混雑 状況を考慮することで精度が向上すると考えている.

全体的にはタクシーを電話で呼び出した場合に遜色の ない移動時間を達成できているが，58 件の配車中，乗 り合いが発生したのは 11 件に過ぎない. 街中で実用に なった場合に一人当たりの運賃を下げるためには，乗り 合いがもう少し多くなければならない．残念ながら小規 模運行実験ではそのデータは採れていない.

\section{(6) 実験で判明した問題点}

両実験後のアンケートやヒアリングにより，事前には 想定していなかった問題もいくつか明らかになった。 そ の多くはタクシー等の小型車両の乗合いに関することで ある．特に女性は男性との乗合い時に酔った客と同乗し たくないとか, 自宅の位置を知られたくないとかの要求 がある．また，現在のタクシー車両（ジャンボタクシー を含む）で乗合せた場合，奥の乗客の乗降の不便さも問 題になる. 今後 SAV 用の車両を新たにデザインし, 乗 降ドアを複数設け，座席ごとの仕切りを導入するなどの 方策が必要に思える.

また，駅やショッピングセンターなど，多くの人が乗 降する場所では，乗客が SAV の位置を，ドライバーが 乗客の位置を知るのが困難な場合があった．地図上で相 手の位置を詳細に表示寸るなどの方法が必要である。ま
た互いの位置以上のランデブー情報の提示（たとえば拡 張現実感を利用するなど）の可能性も探る必要がある.

\section{(7) 今後の課題}

現状ではシステムが動作寸るということの確認に留ま っている. より多くの一般市民や観光客を対象とする社 会実装に向けた今後の課題としては，上記の問題点を解 決するなど, 以下の課題の解決が必要である.

1. 乗客Appのユーザインタフェースの改善 乗客に様々な情報を提供するとともに，リクエス 卜後のキャンセル, 変更, 操作や通信のエラーへ の対応を可能にする必要がある．また，乗車位置， 降車位置を地図上で示寸場合に全体が丁度入りき る縮尺への自動ズーム機能が望まれる

2. 車載Appカーナビとの連携

現在，車載端末では乗客が指示した乗車，降車ポ イント間を直線でつないだルートが表示されてい る. 実際の走行経路はドライバにまかされている が，ドライバからはカーナビとの連携を望む声が 多い，また，乗客App同様に，乗車位置，降車位置 を地図上で示す場合に全体が丁度入りきる縮尺へ の自動ズーム機能（あるいはそのような表示モー ドに移るボタン）の追加が望まれる

3. 車載Appの操作性の向上

押し間違いの取り消し等が必要. 走行時の情報提 示に音声を併用することが望まれる，また，現在 の静電式タブレットでは手袋装着時に操作できな いため，圧力式のタッチパネルの使用が望まれる

4. 通信方式

現在は携帯電話網による通信を行っている. 設備 導入コストは安いが運用コストが高額になる. タ クシー用デジタル無線などの利用が望まれる

5. ユーザとSAVドライバが相互に相手の位置を確認 する方法

現在，SAVの位置は乗客Appで確認できるが，ドラ イバが乗客位置を確認する方法が無い.

6. 空港等で多くの乗客が見込まれる場合の配車や待 ち合わせ方式の洗練が必要

7. ルート検索アプリなどとの連携（当該アプリから の予約など)

8. 学習機能

あらかじめ予測されるデマンドに備えて空き車輛 の配置を行う。

9. 実稼働に向けた料金体系等のデザイン，法的問題 の確認

10. 乗り継ぎの可能性の検討

現状では函館規模の都市を対象と検討を行ってい るが，東京あるいは関東平野といった巨大都市圈 
をカバーする際には領域分割を行って，領域間で は乗り継ぎをする必要があると思われる.

\section{6. サービス連携}

SAVS の運用形態は様々な可能性を持っている．渋滞, 天候の変化や災害などに対して強いことの他に，コンピ ユータによる制御の自由度を活かして，他の様々なサー ビスとの連携が考えられる。派生的な移動という目的と それとは直接に関係しない別の目的を有機的に組み合わ せて実現するのである.

\section{a) 病院との連携}

病院の予約だけでその往復の足を確保寸ることができ る. 特に帰りは診療の進み具合を見て自動的に配車リク エストがなされる.

もう一歩進んで SAV で移動中に診察とか調薬とかが できるかもしれない，現在病院で 2 週間以上の薬を処方 することは禁じられているので，患者は少なくとも 2 週 間に一度の通院を強いられている。これを病院ではなく 患者が別の目的で SAV 乗車中に行うことも考えられる。 つまり，医者が同乗し，診察が必要な患者を重点的に拾 うSAV を定期的に運行するのである. 患者はこの運行 に合わせて乗車するのではなく，通常のショッピングや レストランへの移動時にシステムが自動的にこのサービ スに割り振るのである.

\section{b) レストラン等との連携}

レストランの予約と連動した配車，そして会計時に自 動呼び出しというような連携が可能である、マーケット への買い物なども類似の連携が出来るが，マーケットの 場合はもう一歩進んで，インターネットで購買して SAVで受け取るということも可能であろう.

将来的には SAV が移動レストラン機能を持つという ことも考えられる.

\section{c) 観光との連携}

観光客はバス路線に疎いことが多いので，SAV が便 利であろう、お金があればタクシーでまわるということ も可能ではあるが，SAV を使えばタクシーに近いサー ビスが安価に受けられると考える，京都のように，見所 が街中に散在している観光地では特に便利に違いない. ちなみに SAV は運行形態の自由度が高いので，一日貸 し切りにして使うことも可能である。この場合はハイヤ 一同様の值段設定となる.

\section{d) 図書館との連携}

SAV を使って図書館に行くことも可能であるが，移 動図書館のようなことも可能であろう。あるいは借り出 しを予約した本や，インターネットで購入予約した本が SAV に積まれていて, 別件での移動の途中に受け取る
ように配详することも考えられる。

\section{e) 他の交通機関との連携}

SAVS は都市内全域をカバーすることを前提としてデ ザインしている．都市間は列車や航空機，船等で結ぶ. これらの長距離輸送機関との連携も重要である.

駅や空港に向う乗客が搭乗予定の列車や航空機の情報 （オプション）を入力した場合にはそれらとの接続を保 証するようにする，また，列車や航空機に対して乗客の 到着予定を知らせる．万一渋滞等で遅延が生じた場合に 列車や航空機が乗客待ちをすることも可能である．列車 や飛行機を予約した段階で，自動的に SAV の配車を決 める手もある.

また列車や航空機からの接続として，到着時に駅や空 港に出迎えることが可能である. 到着の遅延等を含め, 事前に情報がわかるのでシステムとしても配車が容易に なる.

\section{7. 結論と将来展望}

これまでにフルデマンド型公共交通サービス SAVS の 運行実験を 2 回行い，世界初の複数台リアルタイム完全 自動配車実験に成功した．函館市内において，全くルー 卜を限定しない乗合い交通で，予約無しに，呼び出して からほぼ5分での配車を実現することができた。

技術的には（ユーザインタフェースなどの細かい部分 を除いて）ほぼ完成したと考えている，一方でこれを実 際に導入するには（いやそれ以前に，より大規模な実証 実験を行ううえでも），タクシーとバスを分離している 法律をはじめとして 5.(7)で指摘したような様々な問題 がある他に，経営者やユーザのマインドが変わって行く 必要がある．規模と対象範囲を広げながら実験と広報を 繰り返し, 徐々に理解を得て行くつもりである.

クラウド化の発展は急速で，バスやタクシーといった 仕組みの違いを超えてモビリティを提供する公共交通シ ステムの実現は，国内でその成否を議論している間に海 外諸地域に先を越される怖れがある22. SAVS は現在, ある候補地域での市街地全域を対象とする実験に向けて 準備を進めている．函館市をはじめ特定の都市で導入を 図るとして，どのような車両がどれくらいの台数必要か は，運行実験によるユーザ動向の変化を観測することな しには算定しづらい．現在，実験時でも実際に料金徵収 はできないため, SP 調査にて利用者の料金感度を把握 すると共に，待ち時間や同乗者の有無など，その他のサ ービスレベルに応じた利用意向を調査する予定である. また，実験時の配車ログ（実績データ）と利用者意向

（SP 調査データ）を組み合わせ，自家用車など他の交 通手段と SAVS との交通手段選択モデルを構築し, 
SAVS のデマンドの時間的分布，空間的分布を推計し， 社会システムとしての導入評価を行う必要があると考え ている，その際，既存の路線バスのサービスレベル（路 線網と料金体系）改変案との比較も実施し，市民など利 害関係者の社会的受容性を得るための基礎判断情報にし ていく必要がある.さらに，自家用車の保有・利用を削 減するモビリティ・マネジメント策などとも融合しなが ら，その都市の需要と政策に見合った運行システムを 徐々に見極めて行く必要があるとも考えている.

謝辞 : 本研究の大部分はRISTEX「問題解決型サービス 科学研究開発プロジェクト」に採択された課題「ITが可 能にする新しい社会サービスのデザイン」として実施さ れている.

\section{注}

[1] 本稿では，SAVサービスの利用者を「ユーザ」， SAVに乗車中のユーザを「乗客」としている.

[2] 将来的にはICカード等を使って乗降確認も自動化す る予定である.

[3] 車両1台のルートに対して行うので最大でも定員の2 乗の計算でよい.

[4] 位置取得間隔はもっと短くすることも可能であるが, 通信量とのトレードオフである. 配車計算に30秒ほ ど要することを想定し，この程度で良いと考えてい る. タクシーは1分で 2 3km走るが，その程度の遅 延は今のところ問題ないと考えている（実サービス 時には交通状況に応じて見直す必要がある）。

\section{参考文献}

1) Ambrosino, G., Nelson, J. D. and Romanazzo, M. : Demand Responsive Transport Services: towards the Flexible Mobility Agency, Italian National Agency for New Technologies, Energy and the Environment, 2004.

2) 森栗茂一(編著) : コミュニティ交通のつくり方, 学芸出版社, 2013.

3) European Commission: The European Innovation Partnership on Smart Cities and Communities - Strategic Implementation Plan, 2013. (http://ec.europa.eu/eip/smartcities/ files/sip_final_en.pdf)

4) Gerla, M., Lee, E.-K., Pau, G. and Lee, U.: Internet of Vehicles: From Intelligent Grid to Autonomous Cars and Vehicular Clouds, Conference Paper for IEEE World Forum on Internet of Things, March 2014.

5) 中島秀之, 小柴等, 佐野涉二, 白石 陽 : Smart Access Vehicle システムの実装, 情報処理学会 DICOMO シンポジウム 2014, 2014.

6) 中島秀之, 田柳恵美子, 松原仁, 平田圭二 : 新しい 交通サービスへの道程, サービス学会 2015 全国大会, 2015.
7) 中島秀之, 白石陽, 松原仁：「スマートシティはこ だて」の中核としてのスマートアクセスビークルシ ステムのデザインと実装, 観光と情報, Vol. 7, No. 1, pp. 19-28, 2011.

8) Nakashima. H., Sano, S., Hirata, K., Shiraishi, Y., Matsubara, H., Kanamori, R., Koshiba, H. and Noda, I.: One cycle of smart access vehicle service development, ICServ2014, pp. 287-295, 2014.

9) 広井良典：コミュニティを問いなおす，ちくま新書, 2009.

10）喜多秀行：交通基本法と地域公共交通計画, IATSS Review, Vol. 37, No. 1, pp. 32-40, 2012.

11) 田柳恵美子, 中島秀之, 松原 仁 : デマンド応答型公 共交通サービスの現状と展望, 人工知能学会全国大 会 2J4-OS-13a-1, 2013.

12) 大和裕幸, 稗方和夫, 坪内孝太 : オンデマンドバス 一公共サービスに於けるイノベーション, オペレー ションズ・リサーチ: 経営の科学, Vol. 51, No. 9, pp. 579-586, 2006.

13）鈴木文彦：デマンド交通とタクシー活用, 地域科学 研究会, 2013.

14) Westerland, Y. and Cazemier, O. C.: The use of taxis for special and the integrated public transport in Sweden and the Netherlands, Presentation at the International Taxi Colloquium Lisbon, 21 September 2007.

15) 加藤博和：公共交通として位置づけられたタクシー が果たすべき社会的役割, 土木計画学研究・講演集, Vol. 49, 2014.

16) 太田正幸, 篠田孝祐, 野田五十樹, 車谷浩一, 中島 秀之: 都市型フルデマンドバスの実用性, 情報処理 学会高度交通システム研究会研究報告 2002-ITS-11-33, pp. 239-245, 情報処理学会, 2002 .

17) Noda, I., Ohta, M., Shinoda, K., Kumada, Y. and Nakashima, H.: Evaluation of usability of dial-a-ride systems by social simulation, In Multi-Agent-Based Simulation III. 4th International Workshop, MABS 2003 (LNAI2927), pp. 167-81, 2003.

18）野田五十樹, 篠田孝祐, 太田正幸, 中島秀之: シミ ユレーションによるデマンドバス利便性の評価, 情 報処理学会論文誌, Vol. 49, No. 1, pp. 242-252, 2008.

19) 野田五十樹, 太田正幸, 篠田孝祐, 熊田陽一郎, 中 島秀之：デマンドバスはペイするか?, 情報処理学会 研究報告, 2003-ICS-131, pp. 31-36, 2003.

20) 小柴等, 野田五十樹, 山下倫央, 中島秀之: 実環境 を考慮したバスシミュレータ SAVSQUID による実運 用に向けたデマンドバスの評価, 合同エージェント ワークショップ\&シンポジウム(JAWS-2013), 2013.

21) Behrisch, M., Bieker, L., Erdmann, J. and Krajzewicz, D.: SUMO - Simulation of Urban Mobility: An Overview, SIMUL 2011, The Third International Conference on Advances in System Simulation, pp. 63-68, 2011.

22) Atasoy, B., Ikeda, T., Song, X. and Ben-Akiva, M. E.: The concept and impact analysis of a flexible mobility on demand system, Transportation Research Part C, Vol. 56, pp. 373-392, 2015.

(2015. 2. 27 受付) 


\section{CONCEPT AND IMPLEMENTATION OF A NEW PUBLIC TRANSPORTATION SYSTEM THAT UNIFIES THE BUS AND TAXI SERVICES}

\section{Hideyuki NAKASHIMA, Itsuki NODA, Hitoshi MATSUBARA, Keiji HIRATA, Emiko TAYANAGI, Yoh SHIRAISHI, Shoji SANO, Hitoshi KOSHIBA and Ryo KANAMORI}

This paper presents the concept of a new transportation system, Smart Access Vehicle System. In the system, the locations and routes of all vehicles are controlled by a computer, and no fixed routes or timetables are necessary. We call it "transportation cloud". The system responds to new demands in real time and provides utility of taxis with cost efficiency of buses. Furthermore, it can flexibly readjust to traffic congestion, accidents, malicious weather and disasters. We conducted operation tests and succeeded in running the system automatically for several days. 